Sosyoloji Derneği, Türkiye

Sosyoloji Araştırmaları Dergisi

Cilt: 17 Sayı:2 - Bahar 2014

Sociological Association, Turkey

Journal of Sociological Research

Vol.:17 Nr.: 2 - Fall 2014

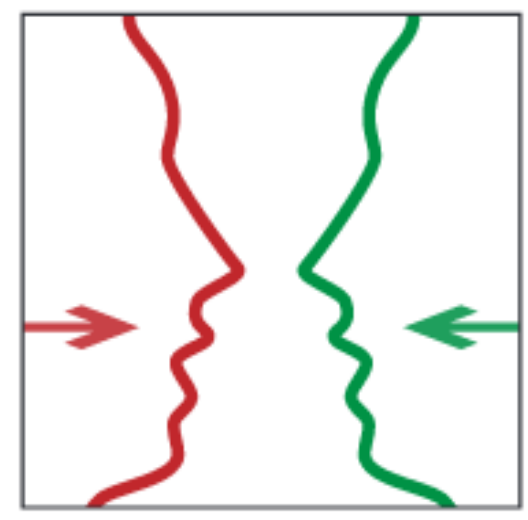

Aged Population and Demographic Changes, Possible Threats to and Policies for Longevity

Meltem İnce YENILMEZ 


\title{
Aged Population and Demographic Changes, Possible Threats to and Policies for Longevity
}

\author{
Assoc.Prof.Dr.Meltem INCE YENILMEZ*
}

\begin{abstract}
The global population is aging at an unpredicted rate with a high decline in fertility. Many of the European Union and Asian countries experience highest life expectancy as compared to the rest of the world. The changing age structure in developing countries has yet started to give an alarming situation. This paper will analyse the possible changes in certain variables including labour force participation, pension system and retirement age. Special emphasis will be placed to a variety of demographic and policy forces that are of vital importance in evaluating the impact of population aging to stop gender discrimination in pension funds. It ends with some policy options dedicated to forming active policies that are essential in coping with the rapidly increasing number of elderly in the world.
\end{abstract}

Key words: Population aging, demography, employment, social security, retirement.

JEL classification: J13, J14, J21, J26, J32. 


\section{Yaşlı Nüfus ve Demografik Değişimler, Uzun Yaşam için Olası Tehditler ve Politikalar}

$\ddot{\mathbf{O} z}$

Küresel nüfus, doğurganlık oranında yaşanan hızlı düşüş ile öngörülemeyen oranda yaşlanmaktadır. Birçok Avrupa Birliği ve Asya ülkesinde dünya ortalamasına göre daha uzun yaşam oranları gözlemlenmektedir. Dikkat çekici bir diğer nokta ise gelişmekte olan ülkelerinde yaş yapılarında oluşan değişimin endişe verici oranlara yaklaşmasıdır. Bütün bu durumlar dikkate alınarak, bu çalışma işgücüne katılım oranı, emeklilik sistemi, emeklilik yaşı ve emek arzı kavramları da dahil olmak üzere değişkenlerin olası artma ve azalma durumları analiz edilmektedir. Emeklilik ödemelerinde yaşanan cinsiyet farklılıklarını önlemek için yapılan yeni uygulamalar ve nüfusun yaşlanmasının etkisi hem demografik hem de politik düzenlemelerde dikkate alınarak incelenecektir. Çalışmada ayrıca dünya genelinde yaşlı nüfusun hızla artmasına bağlı olarak uygulanabilecek aktif politikalardan da bahsedilmektedir.

Key words: Nüfus yaşlanması, demografi, istihdam, sosyal güvenik, emeklilik JEL kodu: J13, J14, J21, J26, J32.

*UC Berkeley, Beatrice Bain Research Group \& Yaşar Üniversity, Department of Economics, meltem.ince@yasar.edu.tr meltemince@berkeley.edu 


\section{Introduction}

The social and economic ogf population aging is a a worldwide phenomenon, with the median age of the world population forecast to rise to 38.1 years in 2050 from 26.7 years in 2000 (Goldstein 2009). This problem has never been pronounced until the population in countries ceased to grow with high level of life expectancy and low level of fertility. This treatment strats a new discussion with a concominant approach of social, economic, medical, political, sociological and other aspects of aging to the literature and each of this phenomeon is reenforced by one another. Yet the length of time of life expectancy differ in country level, every country try to find out an appropriate, significant and sustainable solution either due to their economic or social adherence. Several other problems are drawn about the role of elderly aged and their identity in societies like health, persistance of unemployment, occupational difficulties, social security, savings and earnings. To overcome this burden of dependency of old aged people, fundamental policy decisions as well as creative activities associated with the supportive approaches of a wealthy aged population should be produced. Especially, public and private pensions with beneficial social security schemes must be restructured in return for a rapid rise in elder people and working population.

The purpose of this article is to identify existing debates on population aging and older aged people with its pros and cons. The main objective of the research is to identify the principle social, economic and medical problems associated with population aging and to evaluate the policies and threats subject to problems emerging in aging. Therefore, the paper is constituted in four domains to analyze population aging from economic and social stratification. Each section tries to explain the pros and cons of aging from its own perspective and attitude: (2) demographic bacground of population aging and its sources; (3) fertility, life expectancy and age composition; (4) demographic and age structure changes and macroeconomic challenges of the aged and (5) social security, pensions and health incentives at retirement.

\section{Demographic background of population aging}

For much of the past decades, the populations of many countries, especially in OECD countries have started to face with ageing term. This demographic shock and unexpected degree on population issues become a worldwide phenomenon and has been sparked by providing policies and commonwealth programs in those countries. The baby-boom generation is getting older with a lower fertility and higher longevity. The international debates about demographic 
changes have almost placed in the first rank of the government's population policies. The unexpected change in the age structure of the countries is certainly so dramatic that the economic effect of population aging may damage the living standards of elderly. The number of people over the age of 65 is estimated to reach 1 billion by 2020 and approximately 2 billion by 2050 , which represents 22 per cent of the world's population. The ratio of people aged 65 or over is approximately 13 percent of the OECD population now, which was doubled due to 1950 ' genus. In 50 years from now, this percentage is expected to increase more than 25 percent. Those elderly people are not growing rapidly but also their longevity has increased. As the length of healthy elder increases, social security programs as well as pension funds must be restructured in regards to working population. Since the number of years lived increases, the working age of the elder should be put in balance to avoid the unravelled excess supply of oldage people.

There are many studies in the literature, including this one, showing that increasing population aging and declining fertility rates in the world are the critical issues. Population is a core determinant for development and if the life span is structured, old age begins in 60s which is the crucial age for retirement. From this time, the economic dependency will start till the end of their life. Of course, the policies influence the effect of aging on economic well-being of the older people. Further, the transfers from the working people to the retired are required, but it brings obstacles in many productive fields and their economical well being is lost. In regards to this, many of the younger people would be responsible for their older parents dependency. Since the demographic, social and economical changes have shown an alarming situation, the new legal and cultural efforts must be taken into account either by ceasing age discrimination or by enhancing older people to prolong workforce participation. Otherwise, the problem of social pension programmes and labor supply deficiencies will arise. Among the most commonly used policy change is to regulate the social pension programs for retirement age. The major aim of these programs is to increase the share of older people who will benefit from coverage in their retired age. On the other hand, the debates about population aging need to focus on labor supply deficiencies and social pension programmes. In many countries, the early retirement from the workforce is induced, but reverting the fertility ratio or enhancing women to enter the labor force is often overlooked. If the main aim is to maintain the current level of labor supply in the labor market, countries would consider the productivity loss related to early retirement. 
Consequently, encouragements to rise women's labor force participation be a solution for a significant growth in labor supply in all countries.

However, with this face of difficulties, there is more need for a substantial social protection program that specially addresses the requirements of older people in the wake of population aging. Although the projections demonstrate that the long term consequences of age population aims to increase the fertility rate and regulate the pension arrangements with adaptation of new standards, lack of financial constraints and political instabilities on health care system limit to change the current programmes. Since the countries could not tackle the demographic change with the reforms, there would be a gap between assessing the needs of older people and meeting those needs they require. In order to reduce this wedge, many countries are now reinforcing the improvement of current pension systems. As a result, workers could save for their retirement life. Countries might not be able to cover the full of needs of old people, but they could assess the steps, re-design the programmes and change the situation to win-win scale. The results of the countries confirm the diversity of demographic changes in regards to policy challenges related to aging and pension system. All in all, the risk revealed by population aging might not bring a negative impact on social and economic trends if the essential policies are implemented. On the contrary, population aging would become a challenge. The countries values and reliances would encourage people to adapt the new arrangements, but embracement the programs from one country to another must be meshed alike countries' precisions. As noted at the outset, policy makers should take consideration of these solutions in days to come.

The projections show that the long-term consequences of demographic change should be treated by social policy-makers and politicians whose temporal perspective exceeds the nearest election, with due attention. The changes in social policies aiming at an increase in fertility, increase in labour force participation and reforms of pension systems are at the core of the strategies for the adaptation of social and economic systems to the new demographic patterns. Demographic change cannot be tackled with marginal or partial reforms. On the contrary, the reforms needed to compensate the population decline and ageing will be painful, will affect the entire populations and will reshape the social situation of the next generations. The results also confirm the diversity of demographic and economic activity patterns in Europe: policy challenges related to ageing and its labour market con sequences are not expected to be very dramatic in Scandinavia, but they are going to be profound in the South. Especially in 
countries like Greece, Italy and Spain, a combination of low fertility and low labour force participation may be very unfavourable in the long run.

As the main determinants of aging are known as decrease in fertility rates and increase in mortality rates, population aging will show an exponential rise on the earth. If the aging is accepted as a loss, this global aging is an alarm for governments and policy makers. The World Health Organization drew more comprehensive picture since late 1990s. Healthy and active aged population as well as their participation in all parts of life are the major aging policies of WHO (2011) although there is a contradiction posited between longevity and economic development. What is responsible for the above phenomenon is that social protection to their health needs with sustainable pension system is required to provide continuance of sustainable growth. Yet, economic impact of aging in the world is utterly to be negative. Not only will the cost of older care and financial securities but also decline in personal savings, retirement entitlements and instability in labour market provide severe problems. As the economic development depends on consumption and investment; if one of them shrinks, the stock of assets will decrease. Since the income is more influential in determining the life cycle of an individual, elder ones spend most of their income on medical and health care compared to young cohorts. Therefore, preferences vary across age groups and as a result, consumption will tend to decline in older ages, which will affect economic growth negatively. As a result, long-term demographic and economic scheduling must be handled to highlight the policies that governments will follow revealed by demographic tendencies.

\section{Fertility versus life expectancy: demographic pre and posts}

Female social and economic status leads to a decline in birth giving as well as fertility rates. For an individual woman, the better the socioeconomic standing in the society, the equal status in the work life at least in some jobs. For a society, if women's role and statues start to increase by access to education and employment, the society becomes neutral in gender issues and traditions lose its significance. As a result of this, children preference decline. Thus, a decline in fertility of very young affects the age composition as does a decline in mortality rates (Coale, 1972). After $19^{\text {th }}$ century, especially in under-developing and developed countries, increase in life expectancy could result in a significant increase in the number of young cohorts. But increase in longevity at higher ages will result in a high number of older aged people in 
population. Moreover, when the fertility is low, even immortality could produce a high ratio of older population. Therefore, attention is being directed to changes in biological properties associated with aging. Increase in life expectancy at advanced years may increase the problems associated with population aging which will cause a burden in supporting the older population either in labor market or in undergoing health issues. So pro-longation of later life reenforced the need for governmental provision of support of the aged people and aged support system. In this respect, more importance of the aged structure as a fundamental governor of the proportion of beneficiaries to contributors must be stressed and implication of sub-replacement fertility for future generations should be evaluated.

With regards to the social and economic conjuncture, more employment experience and higher occupational position start to weaken the traditional gender roles because working experience and educational opportunities give more confidence and economic independence to women in most of the countries which increase their capabilities in work force as well (Bolzendahl and Myers, 2004). Women who have higher occupational positions in the labor market are expected to have fewer children or even no children because they are more likely to participate in social and economic environment than their female counterparts and think that children would mitigate their future career possibilities. Becker and Barro (1988), Becker and Tomes (1976), Becker and Murphy (1988) developed a theory of fertility, investment in human capital and public-sector education which yields to a theory of economic growth. But they all forgat to take aging-structure into account. Therefore, education tends to rise women's empowerment and enlightenment by providing better opportunities in work life. All in all, as gender equality is more acceptable and applicable between men and women, it affects women's expectations, social and economic life as well as status in the society. But the result would be a decrease in fertility rates overall. In turn, fertility decision of women will affect the number of children in the population and the future of them when they are young enough to be in the labour force. At the global level, the shift from high fertility to low fertility will reinforce economic development by rising aging. But that is the only expected consequence of the picture. Considering the fact that fertility rates in nearly most of the countries are falling as a result of voluntary preferences of people there will be destabilizing elder cohorts in the future. Efforts are being madeespecially in the countries where the percentage of older people is higher like EU countries.

In Turkey, fertility history is distinctive from EU countries. At the beginning of the 20th century, fertility has been started to decrease but later with some health policies collateral with Ministry of health, total fertility rate is expected to increase in 10 years period. Therefore, in 
Turkey, much of population aging is due to low fertility and age distributions including the tiny baby boom. Figure 1 presents the Total Fertility Rate in Turkey from 1928 to 2013. The figure combines several sources of information. The biggest drop in fertility occurred in 1933 in Turkish Independence war period as well as during the economically and politically difficult years after it. The decline never slowed down after that, but nevertheless, in 2000 Total Fertility Rate fell below replacement level of 2.3 births per woman and stayed at the level of around 2 births per woman for the next 13 years.

Figure 1: Total fertility rate in Turkey, 1924-2013

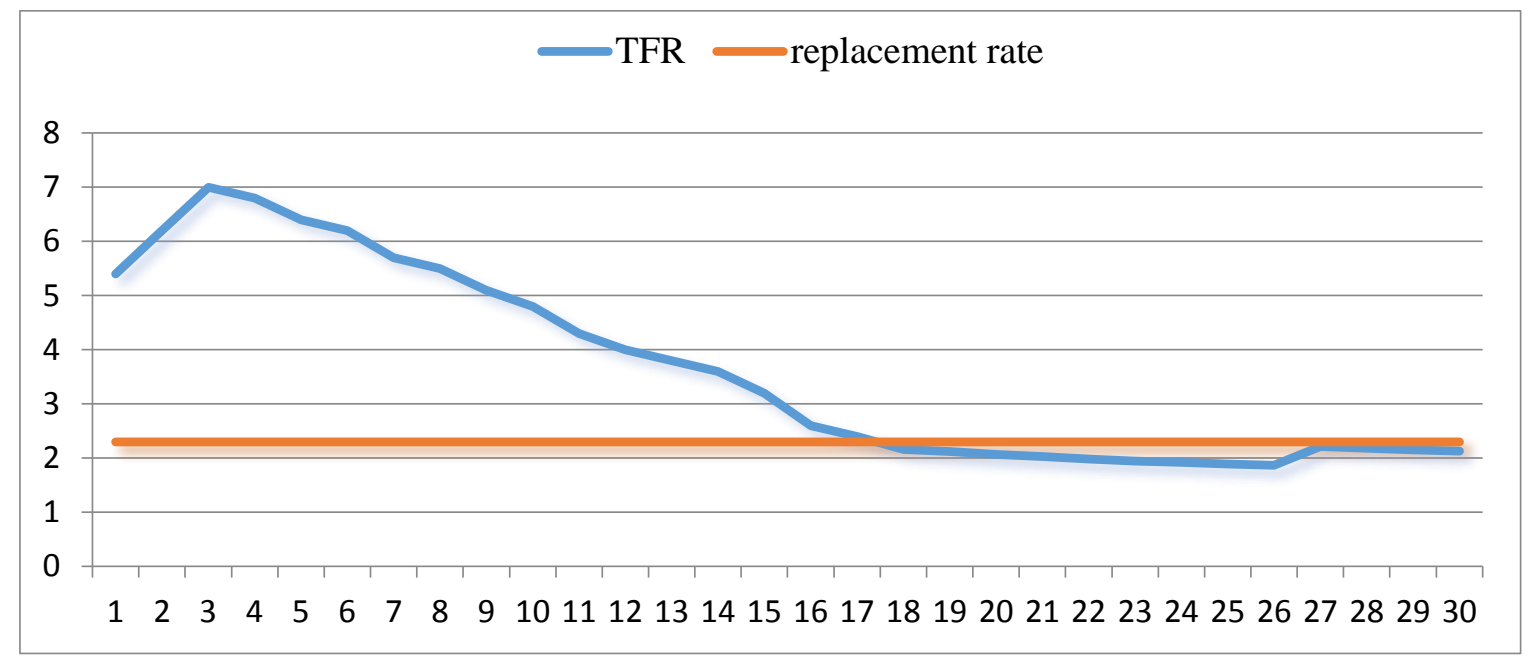

Source: TUIK, 2013.

Indeed, it is not surprising that periods of high uncertainty of economic instability and socioeconomic crisis have a negative impact on fertility. Therefore, decrease in fertility will lead to population aging which affects not only Turkey, but all industrialized countries. As Table 1 shows below, the ratio of people aged 65 and over in the OECD will increase from 13 percent to more than 20 percent within the next 20 years. Among the seven large OECD countries, the aging will be mostly expected in Germany, and the least influenced countries will be United Kingdom and the United States. In Germany, the ratio of elderly people will increase nearly to more than a quarter of the population within the next 20 years. 
Table 1: Elderly population aged 65 and over in largest OECD Countries

\begin{tabular}{l|llll}
\multicolumn{1}{c|}{1950} & 1980 & 1990 & 2040 \\
\hline \hline Canada & 7.7 & 9.5 & 11.4 & 23.6 \\
France & 11.4 & 14 & 13.8 & 22.7 \\
Germany & 9.4 & 15.5 & 15.5 & 26.3 \\
Japan & 5.2 & 9.1 & 11.4 & 21.9 \\
Italy & 8 & 13.5 & 13.8 & 22.3 \\
United States & 8.1 & 11.3 & 12.2 & 20.5 \\
United & 10.7 & 14.9 & 15.1 & 20.1 \\
Kingdom & & 12.2 & 13 & 20.4 \\
Average & 8.5 & 13 & \\
OECD & & & &
\end{tabular}

Source: OECD, 2013.

As of shown in Figure 2 below, from the beginning of 2000, it is observed that the share of young cohorts in total population is quite close to each other. Moreover, the age structure of turkey is seen to be similar to the countries that have stable age structure. This result shows that the size of the population will start to stagnate gradually from that year. Based on the population pyramid shown in Figure 2, the level of mortality is changing very rapidly. the period 1935 and 1965 draws an attention to the high rate of mortality in Turkey. After 1970, the rapid contraction in population pyramid starts to disappear and since 1990s, the mortality rate is even more slowly shrinking.

Figure 2: Population age groups by sex in Turkey, 1935-2030.
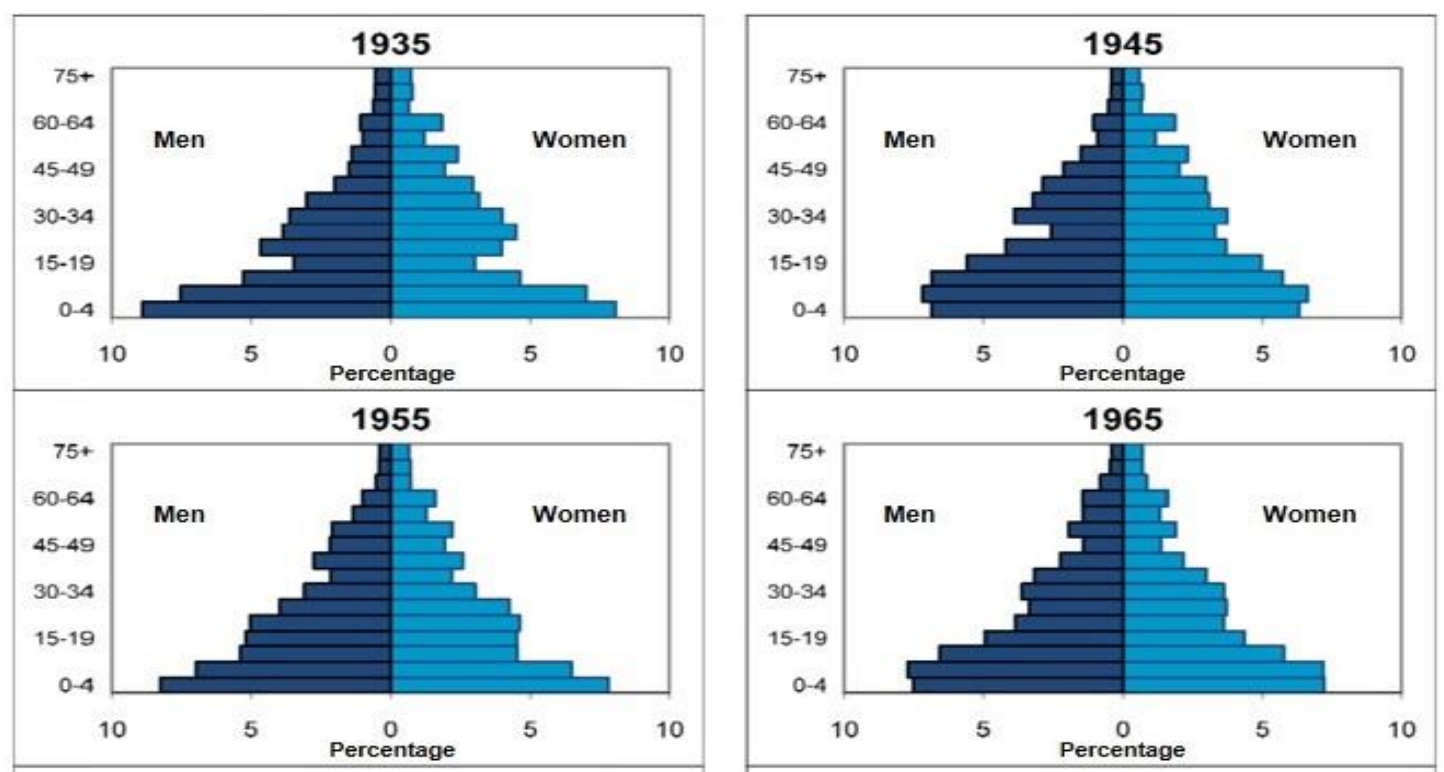

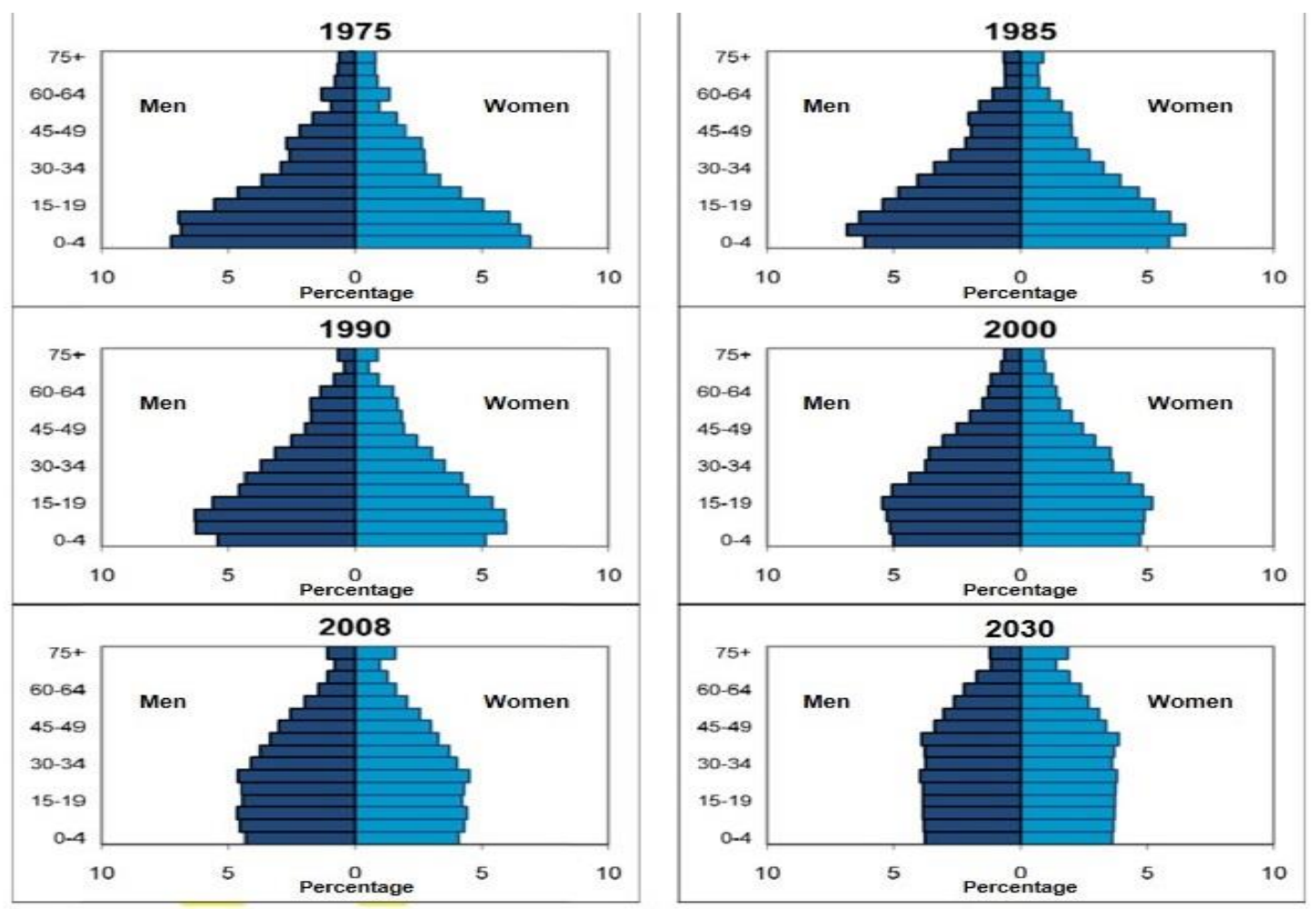

Source: TUIK; 1937, 1949, 1961, 1969, 1982, 1989, 1993, 2003, 2010, 2013

\section{Demographic changes and macroeconomic challenges}

According to literature, the rise in population decreases the economic growth of a country. In the beginning of 1990s, economists believe in a hypothesis that as the population increases, the economic growth increases (Bloom, Canning and Sevilla, 2003). Therefore, there is a complicated relationship between labour force and population aging with a significant decrease in fertility rates. The macroeconomic consequences of population aging in countries will generally vary due to people's willingness to be in the labor market. The higher the labor supply among older people, the less leisure they will have which will lead to have difficulty in finding the appropriate occupations. For instance, to balance the works in the labor market, some works should be transferred from young cohorts to older aged people. It will also bring opportunities to elderly to cover their expenses in social security's especially in care work and Medicare.

The human capital model which was formulated by Becker (1964) was modified by Becker and Chiswick (1966) in the lens of cost of investment in human capital to earnings potential. As of earnings forgone in investment within the time period, the human capital stock invested in the accumulation of human capital will maximize the value of the earnings over lifetime. Depending upon this context, aging is directly related with human capital stock and 
changing valuations of income. As people move into the older age stage, no worth to say that their productive powers, capacity to work, capacity to find a suitable job and fulfilling the requirements of the jobs start to decline. The major factor of this decline is the state of human capital, physical and mental powers as well as psychological effects associated with the process of aging. As stated by Eisele (1974), the macroeconomic significance of population aging is directly affected by the size and the changes of the population describable as old.

Uhlenberg (1992) indicates that obstacles in providing the sustainable and suitable working conditions for older aged people will result with exploring their abilities and experiences. Sandell (1977 as cited by Uhlenberg, 1992) states that to struggle the discrimination older workers face, additional efforts are needed to reduce these challenges to obtain productive and sustained employment of old people. Zoubanov (2000) presents some forms as gradual transition to retirement for Germany, decreased working hours for France, hiring older workers for France and Germany. As specified, the fall in participation rates at young ages is a major phenomenon from supply-side and must be acquired special attention to increase the qualification in a labour market and productivity. However, the concerns about the low youth unemployment is an outcome of rising educational attainment and when this is combined with retirement age of 55, the turnover will be lower (Hoem, 2000). So in an aging society, special attention should be focused on decreasing job declines for young ages and increasing the labour force participation rates for older people.

By 2020, ILO reports that the labour force in Europe, Russia, East Asia (Japan, China, Singapore) and India will be lower than now (ILO, 2004a). The reason behind is the decrease in fertility rates and increase in older population. Other things equal, increase in fertility and labour productivity of older workers must be considered to overcome the problems. Yet, labour force is also important determinant as well as demographic trends for providing suitable solutions. Although larger part of the population becomes older, life expectancy keeps on increasing. Workers start to leave the labour force at younger ages, which brings more dramatic problems. As settings and data in the literature represent, labour force participation are utterly critical to forecast labour supply for the coming decade. Assumptions predict that the number of young cohorts in the share of the total population will be decreasing by 2050 especially in developing and under-developed countries; a development is necessarily required to compensate and guide these people for their older ages. Since the workers over 65 will be healthier and educated in the future, they can provide precious contribution either to economic growth or to the labour force. Not only in advanced countries but also in developing countries 
as well, many elder cohorts want to continue their jobs with flexible hours of working instead of retiring. But will participation of old people in the labour force offset the decline in supply of labour and decline in labour productivity?

When Turkey is examined in this issue, labor force participation rates for men at aged between 25 and 54 declined while it declined sharply after aged 55 in the years of 1970 and 2000. But after 2000, labor force participation rates above age 55 increased slightly and men's age at retirement likewise increased by 1.7 to 2.3 in 2010 . But the trends for women are more complex in their labor force participation. Although their mean age at retirement has started to rise by 1.2 since 2000, they are still below men's ratios. But declines in fertility rate have certainly affected the changing age distribution of the labor force, which indeed will show its significant contribution in future periods.

Regrettably, the labor force participation for both women and men are mitigating in Turkey since 2005. While it was 81 percent for men and 34 percent for women in the late 1980s, it dropped to 73 percent for men and 25 for women in 2012 as indicated in Figure 3. Of course, immigration from rural to urban areas within regions affects female labor force participation rates by not meeting the employment criteria. But the same cases are very welcoming situations in European Countries and this immigration does not evoke a significant effect on females' like what women are facing in Turkey. For instance, Turkey has structural problems in solving these obstacles, which need urgent solutions in order to find thriving remedies for elder people.

Figure 3: The change in labor force participation rate. $1988-2008$

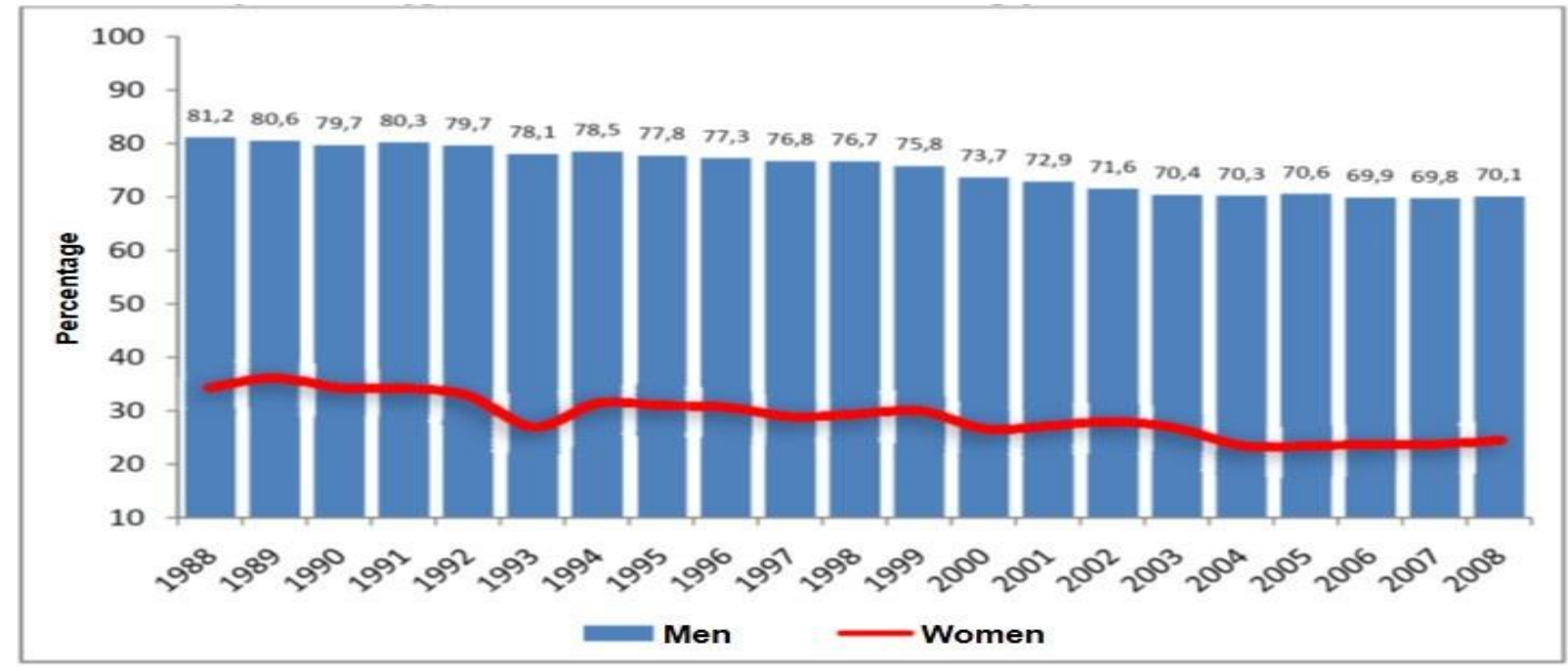

Source: TUIK; 2010m, 2010n, 2010o. 
There are many changes that will facilitate women's and older aged people's work. Government does not need to concentrate on distortionary incentives and try to provide plans depending on this issue, contrary that may be eliminated especially in social security plans. Ensuring more flexible work hours and allowance for older retirement will make it easier to continue working and to be in the labor market at least to cover their Medicare.

From another point of view, the effect of aging on productivity is not fast enough to pull up with the changing in labour market. With increasingly older people in the labour supply, the gap between age and productivity will rise. Other things equal, Lehman (1953b) states that there is a positive correlation between age and learning at younger ages as the productivity increases in science and athletics at age of 20 s by reaching its highest level in 40 s and starts to decline thereafter. Consequently, the change in age structure will be conducted with a change in total productivity, which is a result of selecting the jobs according to productivity. According to a survey carried out by Barth (1993), elder workers rated the survey as acquiring better skills and showing positive attitudes towards difficulties than the younger ones where they are facing problems with medical care costs and training for the new innovations.

Another option to balance the reverse effect of aging in population is to provide job opportunities that are under-represented in the labour force. The manifested group here is the women in the working age. Although there have been some contradictory solutions of this involvement as mitigating fertility, that may be a forceful alternative for preventing the decrease in the labour supply. Worldwide women live approximately 4.5 years more than men, which show a more dramatic outcome. Most of the centenary - oldest old- is women in the world on average. Although the discrimination and violence against women lack of access to health and medical care, low level of educational enrolment, even female infanticide and neglecting them in the society - especially in under-developed countries, women have higher life expectancy. In the next decades, if all of those circumstances are improved, the life expectancy of women will step up on men's. On the other hand, women generally enter the workforce at older ages because of economic factors like lack of access to health care or inadequate income. In most of the developing countries, they still suffer from working without social contracts and in unhealthy working conditions. Older women are at the bottom of heap. They often do not have social security or insurance and face with more medical problems. Concerning all of those cases, it can be concluded that female labour force participation has to be boosted either by shortening the working hours with more flexible time periods or providing them a guarantee of getting the 
same job and position after maternity. Yet, women's position under these circumstances is one of the most significant factors while discussing the population aging in labour force participation.

\section{The retirement and social security}

Population aging may have a huge impact on national saving rates in many ways like changing the saving behavior of many people at different age level as well as not having sufficient saving on pension and health care. Although many of people are aware of this health insurance challenges for their future retirement age, they even do not try to protect themselves by saving or assets holding today to protect their increasing life expectancy. Therefore, predicted population aging is already straining public pensions and private health care systems in many countries, which is resulted with reduced benefits or increased taxes in the future. Of course, a variety of factors influence the percentage of pre-retirement income and pension a worker receives in the form of retirement benefits either in public or private pension. In addition to this pension benefit, some workers are unable to provide supplementary retirement income due to dissaving during their life time. As Diamond (1977) states inadequate savings would be a widespread phenomenon for elderly and distributed equally to the bottom of the income distribution. Since improvement in health has a contributing impact on ability to work until an advanced age, saving as well as consumption has significant effect on life-cycle of older people (Thurow, 1969).

However, economic participation drops sharply after the retirement age of 65 in countries with high pension coverage, which means the impact of population aging, is directly related to pension financing. It is very high in countries where public finances the pensions. There are many examples for this situation as East Asia and India. In East Asian countries, governments spend approximately 2 per cent of their GDP to pensions and it is expected to rise to 4 per cent till 2030. By 2050, the ratio will rise to nearly 8 per cent especially in South Korea, Taiwan and Japan. Pensions vary from country to country. In Latin America, as in most emerging countries, very few older people are covered with pensions since they cannot save for their elder life. By reason of mitigating fertility rates, less and less young workers can support old people (Mohan, 2004). In any case, social protection is the main activity that the 
governments obtain to provide an efficient and better public support for growing as a safeguard in order to cover their health care.

Despite important steps of social protection and pension policies taken into consideration by governments to increase the wealth of older people, many emerging countries still show very small proportion and efforts for the older people needs and requirements. However, pensions are important, especially in developing countries, this coverage is ignored. On the other hand, countries like USA and Canada do not enhance the protection and still do not provide adequate income for older people's retirement life. Even in some developed countries such as the United States, public pension programmes like Social Security may not provide sufficient income for most people during retirement. Many Latin American countries have using different pension systems. Coverage of employed people varies from 52 per cent in Brazil to 14 per cent in Paraguay. In some Latin American countries such as Argentina, Brazil, Chile and Uruguay, older people are richer compared to Bolivia, Colombia, Costa Rica and Mexico (Dethier, Pestieau and Rabia, 2010). One reason is that most of these Latin American countries obtain their pension system from Pay-As-You-Go - public oriented- to private individual social protection system to preserve their savings in case of any problems older people will face when they are elder (Corbo, 2004). So obligatory pension directly affects personal savings negatively whereas it is expected to give incentive to save more for older ages. However, India is another example for benefit- contribution pension, which is managed by government. Most workers in the formal sector - at about 10 per cent of the labour force- are involved in one of the pension programmes the government provides. These programmes consist of lump-sum pay-outs, annuities or a set of benefit contribution (Eide, Krause and Roses, 2001).

The common way of enhancing voluntary personal saving for retirement age has been implemented through tax incentives. Unfortunately, that may become very expensive and it can be applied more high-income earners. In general, people do not want to spend their whole working life just to make a contribution for voluntary personal saving pensions. They even do not know whether the plan is sufficient or not. The reason indeed depends on the life expectancy as well as the value of the pension, how long they will pay and at the end, how much interest they will earn from the saving. As the life expectancy differs by countries, the retirement ages differ as well. Such as the pension age is age 65 in most of the OECD countries whilst it is 60 in France, 62 in Hungary and will be 67 in the United States when the reform is applied (OECD, 2010). 
On the other hand, it is known that pension systems vary across countries and every country uses different models. In general, governments obtain a mix of public and private pension model in which public pensions are legal and financed by PAYG principal. However, the private pensions in some countries are obligatory although most of the countries accept these funds to be paid voluntarily. That can be pushed forward either by employment based or personal saving pension. England, Canada and USA reach the aim of voluntarily employment based pension policy and approximately over 40 per cent of their employees get involved in this plan. Germany and Japan nearly reach this proportion. But still in France, Finland, Spain and Italy, less than 10 percent of employees are covered by voluntarily employment based pension plans (OECD, 2012).

There is great heterogeneity for retirement. Being successful or not is another moot point but as lower income people have very few assets or savings, the higher social security replacement rates at low incomes, the lower the asset income for future benefits. For instance, diversified policy options and plans could be revealed for retirement savings and security. On the other hand, encouraging later retirement by letting workers to prepare for a shorter retirement may be another solution. While deciding on the new forms of health insurance plans against the risks of longevity, requirement for long-term care, inflation, and unemployment concerns as well as the possibility of dissaving could also be taken into consideration. Forcing public and private pension with re-structured health insurance programs on more sustainable fundaments would be important subtitles to look over in laying a scheme.

All in all, the long-term objective of the developed countries is to make the their country the most dynamic knowledge based economy with a high economic growth that provides better jobs, health care and education. Especially, Scandinavian countries and also Germany are relatively providing more benefits either for older people or the ones withdrawals from the labour force earlier to have better pension system compared to other developed countries (Howse, 2006). In these countries, the increasing amounts of personal savings are directed towards pension funds for retirement. To offset the growth in demand for pension system due to increase in older people associated with population aging, social security system must be reformed. The reforms are debated and they will put into action before 2015 . 


\section{Concluding remarks}

There are many studies in the literature, including this one, showing that increasing population aging and declining fertility rates in the world are the critical issues if not getting overwhelmed. Population is a core determinant for development and if the life span is structured, old age begins in 60 s which is the crucial age for retirement. From this time, the economic dependency will start till the end of their life. Of course, the policies influence the effect of aging on economic well-being of the older people. Further, the transfers from the working people to the retired are required, but it brings obstacles in many productive fields and their economical well being is lost. In regards to this, many of the younger people would be responsible for their older parents dependency. Since the demographic, social and economical changes have shown an alarming situation, the new legal and cultural efforts must be taken into account either by ceasing age discrimination or by enhancing older people to prolong workforce participation. Otherwise, the problem of social pension programmes and labor supply deficiencies will arise.

Among the most commonly used policy change is to regulate the social pension programs for retirement age. The major aim of these programs is to increase the share of older people who will benefit from coverage in their retired age. On the other hand, the debates about population aging need to focus on labor supply deficiencies and social pension programmes. In many countries, the early retirement from the workforce is induced, but reverting the fertility ratio or enhancing women to enter the labor force is often overlooked. If the main aim is to maintain the current level of labor supply in the labor market, countries would consider the productivity loss related to early retirement. Consequently, encouragements to rise women's labor force participation be a solution for a significant growth in labor supply in all countries.

However, with this face of difficulties, there is more need for a substantial social protection program that specially addresses the requirements of older people in the wake of population aging. Although the projections demonstrate that the long term consequences of age population aims to increase the fertility rate and regulate the pension arrangements with adaptation of new standards, lack of financial constraints and political instabilities on health care system limit to change the current programmes. Since the countries could not tackle the demographic change with the reforms, there would be a gap between assessing the needs of older people and meeting those needs they require. In order to reduce this wedge, many countries are now reinforcing the improvement of current pension systems. As a result, workers could save for their retirement life. Countries might not be able to cover the full of needs of 
old people, but they could assess the steps, re-design the programmes and change the situation to win-win scale. The results of the countries confirm the diversity of demographic changes in regards to policy challenges related to aging and pension system. All in all, the risk revealed by population aging might not bring a negative impact on social and economic trends if the essential policies are implemented. On the contrary, population aging would become a challenge. The countries values and reliances would encourage people to adapt the new arrangements, but embracement the programs from one country to another must be meshed alike countries' precisions. As noted at the outset, olicy makers should take consideration of these solutions in days to come.

\section{Özet}

Doğurganlık oranında yaşanan hızlı düşüş ve yaşam beklentisindeki hızlı artış, global olarak yaşlanma oranında öngörülemeyen bir arışa neden olmaktadır. Birçok Avrupa Birliği ülkesi ve Asya ülkesinde dünya ortalamasına göre daha düşük doğurganlık oranı ve daha uzun yaşam oranları gözlemlenmektedir. Dikkat çekici bir diğer nokta ise gelişmekte olan ülkelerinde yaş yapılarında bir değişim olması ve artan yaşlanma oranının endişe verici oranlara yaklaşmasıdır. İnsanlık tarihinde ilk kez 2050 yılına gelmeden, dünya genelinde yaşlı insanların sayısının genç nüfusa eşit olması bekleniyor. Çalışma çağındaki genç nüfusta yaşanan azalma, işgücüne katılım oranını düşürerek emekli insan sayısında bir artışa neden olması öngörülmektedir. Bağlılık oranlarında yaşanacak düşüşte bunun bir nedenidir. Demografik gelişmelerde yaşanan değişimler 65 yaş ve üstü yaşlı grubun daha hızlı oranda artmasına neden olmaktadır. Bu durum aktif emek piyasasında da etkisini gösterecek, işgücüne katılan genç nüfusta azalma yaşanacaktır. Bunun sonucu olarak yaşılı grup emek piyasasında daha uzun süre çalışmak zorunda kalacak ve emeklilik yaşı daha da artacaktır. Kısaca yaşlılık oranında yaşanan artış ekonomik büyümeyi ve emek piyasasını etkileyecektir. Bireysel tüketim oranları, yatırımlar ve tasarruflar yaşlara göre farkl1lık göstermektedir. Her ne kadar hükümetler, sosyo-demografik gelişmelere bağlı olarak ortaya çıkan problemlere odaklansalar dahi emeklilik yaşının ötelenmesi hem gelişmiş hem de gelişmekte olan ülkeler için işgücü piyasasında sıkıntıya kısa vadeli çözüm yaratmaktadır. Çin gibi nüfusu yüksek olan bazı ülkeler istihdam kısıtını çözmek için işsiz ya da yeterli düzeyde çalıştırılmayan- yarı zamanlı- kişileri emek piyasasına dâhil 
ederken, nüfusu hâlihazırda az olan ülkelerin böyle bir avantajı olmadığı için gerek ekonomik büyüme gerekse refah dağılımında problemleri zamanla artmaktadır. $\mathrm{Bu}$ açıdan değerlendirildiğinde ise nüfus içinde yaşlıların oranının artışı ile birlikte, gerek sağlık gerekse sosyal gereksinimlerinin karşılanamaması ileriki yıllarda gelişmiş ya da gelişmekte olan ülkeler için önemli bir sorun olarak ortaya çıkmaktadır. Bütün bu durumlar dikkate alınarak, bu çalışma yaşlı insanların yeniden değerlendirmesinin gelecekte emek piyasasında nasıl etkin olabileceği teorik olarak incelemektedir. İşgücüne katılım oranı, emeklilik sistemi, emeklilik yaşı ve emek arzı kavramları da dâhil olmak üzere değişkenlerin gelecekte yaşanabilecek olası artma ve azalma durumları analiz edilmektedir. Emeklilik ödemelerinde yaşanan cinsiyet farklılıklarını önlemek için yapılan yeni uygulamalar ve nüfusun yaşlanmasının ekonomik büyüme üzerine olan etkisi hem demografik hem de politik düzenlemeleri de dikkate alınarak incelenecektir. Çalışmada ayrıca yaşlı nüfusun hızla artmasına bağlı olarak uygulanabilecek aktif politikalardan da bahsedilmektedir. 


\section{REFERENCES}

BETTIO, F.

2008 "Occupational Segregation and gender wage disparities in developed economies: should we still worry?". iç. Frontiers in the Economics of Gender (der. F. BTTIO and Alina Verashchagina). Routledge: Siena Studies in Political Economy.

BLOOM, D.E.; CANNING, D. and SEVILLA, J.

2003 "The demographic dividend. A new perspective on the economic consequences of population change”. Rand document MR-1274. Santa Monica, CA: RAND. P.69-78.

BOLZENDAHL, C. and MYERS, D.

2004 Feminist Attitudes and Support for Gender Equality: Opinion Change in Women and Men, 1974-1998. Social Forces (83): 759-90.

CORBO, V.

2004 "Policy Challenges of Population Aging and Pension Systems in Latin America", inc. Federal Reserve Bank of Kansas City Annual Economic Policy Symposium on "Global Demographic Change: Economic Impacts and Policy Challenges" Jackson Hole, WY, p.1-21.

DIAMOND, P.

1977 “A Framework for Social Security Analysis", Journal of Public Economics, 8(3):275298.

DETHIER, J.J.; PESTIEAU, P. and RABIA, A.

2010 "Universal Minimum Old Age Pensions: Impact on Poverty and Fiscal Cost in 18 Latin American Countries". World Bank Policy Research Working Paper 5292. Retrieved December 5, from World Bank http://www-wds.worldbank.org/external/default/WDSContentServer/ WDSP/IB/2010/05/06/000158349_20100506135339/Rendered/PDF/WPS5292.pdf

EIDE, A.; KRAUSE, C. and ROSAS, A.

2001 Economic, Social and Cultural Rights: a textbook. The Hague: Kluwer Law International.

EISELE, F.R.

1974 "Political Consequences of Aging", The Annals of the American Academy of Political and Social Science, V:415.

GOLDSTEIN, J.R.

2009 "How Population Age". iç. International Handbook of Population Aging (der. P. Uhlenberg ), New York: Springer.

HOEM, B.

2000 "Entry into motherhood in Sweden: The influence of economic factors on the rise and fall in fertility, 1986-1997”, Demographic Research, 2(4), p.1-28. 
HOWSE, K.

2006 "Pension reform and age of entitlement rules", Ageing Horizons, No: 5, p.3-11.

International Labour Office

2004 A Fair Globalization: Creating Opportunities For All, Geneva: International Labour Office.

LEHMAN, H. C.

1953 "The ages of scheduled participants at the 1948", American Psychologist, No: 8.

MOHAN, R.

2004 "Fiscal Challenges of Population Aging: The Asian Experience". Paper presented at Symposium on Global Demographic Change: Economic Implications and Policy

Challenges. Jackson Hole, Wyoming.

OECD

2012 Closing the pension gap: the role of private pensions, OECD: Paris.

OECD

2012 Performance of pension funds, OECD: Paris.

OECD

2013 Pension Markets in Focus, OECD: Paris

SANDELL, S.H.

1977 "Women and the economics of family migration". Review of Economics and Statistics, 59(4), p. 406-14.

THUROW, L.C.

1969 "The Optimum Lifetime Distribution of Consumption Expenditures", American Economic Review, 59:324 - 330.

Türkiye İstatistik Kurumu

19371935 Genel Nüfus Sayımı Türkiye Nüfusu, Yayın No:75. Ankara.

Türkiye İstatistik Kurumu

19441940 Genel Nüfus Sayımı, Yayın No: 158. Ankara.

Türkiye İstatistik Kurumu

1949 Genel Nüfus Sayımı 1945, Yayın No: 286. Ankara.

Türkiye İstatistik Kurumu

19541950 Genel Nüfus Sayımı, Yayın No: 359. Ankara.

Türkiye İstatistik Kurumu

19611960 Genel Nüfus Sayımı, Türkiye Nüfusu, Yayın No:452. Ankara. 
Türkiye İstatistik Kurumu

19641955 Genel Nüfus Sayımı, Türkiye Nüfusu, Yayın No:399. Ankara.

Türkiye İstatistik Kurumu

19691965 Genel Nüfus Sayımı: Nüfusun Sosyal ve Ekonomik Nitelikleri, Yayın No: 568. Ankara.

Türkiye İstatistik Kurumu

19731970 Genel Nüfus Sayımı: Nüfusun Sosyal ve Ekonomik Nitelikleri, Yayın No: 690. Ankara.

Türkiye İstatistik Kurumu

19821975 Genel Nüfus Sayımı: Nüfusun Sosyal ve Ekonomik Nitelikleri, Yayın No: 988. Ankara.

Türkiye İstatistik Kurumu

19841980 Genel Nüfus Sayımı: Nüfusun Sosyal ve Ekonomik Nitelikleri, Yayın No: 1072. Ankara.

Türkiye İstatistik Kurumu

19891985 Genel Nüfus Sayımı: Nüfusun Sosyal ve Ekonomik Nitelikleri, Yayın No: 1369. Ankara.

Türkiye İstatistik Kurumu

1993a 1990 Genel Nüfus Sayımı: Nüfusun Sosyal ve Ekonomik Nitelikleri, Yayın No: 1616. Ankara.

Türkiye İstatistik Kurumu

1993b 1989 Turkish Demographic Survey, Prime Ministry of Republic of Turkey Ankara.

Türkiye İstatistik Kurumu

1995 The Population of Turkey, 1923-1994: Demographic Structure and Development. Yayın No: 1716. Ankara.

Türkiye İstatistik Kurumu

20011998 Evlenme İstatistikleri, Türkiye İstatistik Kurumu, Yayın No: 2481. Ankara.

Türkiye İstatistik Kurumu

20032002 Türkiye İstatistik Yıllığı, Türkiye İstatistik Kurumu, Yayın No: 2779. Ankara.

Türkiye İstatistik Kurumu

20032000 Genel Nüfus Sayımı: Nüfusun Sosyal ve Ekonomik Nitelikleri, Türkiye İstatistik Kurumu, Yayın No: 2759. Ankara.

Türkiye İstatistik Kurumu

2008 Evlenme İstatistikleri 2007, Prime Ministry of Republic of Turkey, Yayın No: 3173. Ankara. 
Türkiye İstatistik Kurumu

2009 Nüfus Projeksiyonları: 2008-2050, Yayınlanmamış çalışma.

Türkiye İstatistik Kurumu

2010m Kurumsal Olmayan Nüfusun Yıllar ve Cinsiyete Göre İşgücü Durumu, 19881999, http://www.tuik.gov.tr/PreIstatistikTablo.do?istab_id=542, Retrieved on: 15.11.2014

Türkiye İstatistik Kurumu

2010n 2000-2006, Kurumsal Olmayan Nüfusun Yıllar ve Cinsiyete Göre İşü̈cü Durumu, http://www.tuik.gov.tr/PreIstatistikTablo.do?istab_id=569, Retrieved on: 15.11.2014

Türkiye İstatistik Kurumu

2010p Ekonomik Faaliyete Göre İstihdam Edilen Nüfus, 1980-2000, http://www.tuik.gov.tr/PreIstatistikTablo.do?istab_id=214Retrieved on: 15.11.2014

UHLENBERG, $\mathrm{P}$.

1992 "Population aging and social policy". Annual Review of Sociology, No: 18, p. 449- 74.

United Nations

2010 World Population Prospects: the 2006 Revision. Fact Sheet on Aging. New York, NY: UN.

United Nations

2012 World Population Prospects: the 2010 Revision. New York, NY: UN.

WHO

2011 Global Health and Aging, NY: US National Institute of Aging.

ZOUBANOV, A.

2000 "Population ageing and population decline: government views and policies", expert group meeting on policy responses to population ageing and population decline. United Nations Department of Economic and Social Affairs, Population Division, p.1-15. New York: UN. 